\title{
Large-scale plasma metabolome analysis reveals alterations in HDL metabolism in migraine
}

Gerrit L.J. Onderwater, MD, Lannie Ligthart, PhD, Mariska Bot, PhD, Ayse Demirkan, PhD, Jingyuan Fu, PhD, Carla J.H. van der Kallen, PhD, Lisanne S. Vijfhuizen, BSc, René Pool, PhD, Jun Liu, MD, Floris H.M. Vanmolkot, MD, PhD, Marian Beekman, PhD, Ke-xin Wen, MD, Najaf Amin, PhD, Carisha S. Thesing, MSc, Judith A. Pijpers, MD, Dennis A. Kies, MD, Ronald Zielman, MD, PhD, Irene de Boer, MD, Marleen M.J. van Greevenbroek, PhD, Ilja C.W. Arts, PhD, Yuri Milaneschi, PhD, Miranda T. Schram, PhD, Pieter C. Dagnelie, PhD, Lude Franke, PhD, M. Arfan Ikram, MD, PhD, Michel D. Ferrari, MD, PhD, Jelle J. Goeman, PhD, P. Eline Slagboom, PhD, Cisca Wijmenga, PhD, Coen D.A. Stehouwer, MD, PhD, Dorret I. Boomsma, PhD, Cornelia M. van Duijn, PhD, Brenda W. Penninx, PhD, Peter A.C. 't Hoen, PhD, * Gisela M. Terwindt, MD, PhD, * and Arn M.J.M. van den Maagdenberg, PhD, * on behalf of the BBMRI Metabolomics Consortium

Neurology ${ }^{\circledR}$ 2019;92:e1899-e1911. doi:10.1212/WNL.0000000000007313

\author{
Correspondence \\ Prof. van den Maagdenberg \\ A.M.J.M.van_den_ \\ Maagdenberg@lumc.nl
}

\section{Abstract \\ Objective \\ To identify a plasma metabolomic biomarker signature for migraine.}

\section{Methods}

Plasma samples from 8 Dutch cohorts ( $n=10,153: 2,800$ migraine patients and 7,353 controls) were profiled on a ${ }^{1} \mathrm{H}-\mathrm{NMR}$-based metabolomics platform, to quantify 146 individual metabolites (e.g., lipids, fatty acids, and lipoproteins) and 79 metabolite ratios. Metabolite measures associated with migraine were obtained after single-metabolite logistic regression combined with a random-effects meta-analysis performed in a nonstratified and sex-stratified manner. Next, a global test analysis was performed to identify sets of related metabolites associated with migraine. The Holm procedure was applied to control the family-wise error rate at $5 \%$ in single-metabolite and global test analyses.

\section{Results}

Decreases in the level of apolipoprotein A1 $(\beta-0.10 ; 95 \%$ confidence interval $[\mathrm{CI}]-0.16$, -0.05 ; adjusted $p=0.029)$ and free cholesterol to total lipid ratio present in small high-density lipoprotein subspecies (HDL) $(\beta-0.10 ; 95 \% \mathrm{CI}-0.15,-0.05$; adjusted $p=0.029)$ were associated with migraine status. In addition, only in male participants, a decreased level of omega-3 fatty acids $(\beta-0.24 ; 95 \% \mathrm{CI}-0.36,-0.12$; adjusted $p=0.033)$ was associated with migraine. Global test analysis further supported that HDL traits (but not other lipoproteins) were associated with migraine status.

\section{Conclusions}

Metabolic profiling of plasma yielded alterations in HDL metabolism in migraine patients and decreased omega-3 fatty acids only in male migraineurs.
*These authors contributed equally to this work.
From the Departments of Neurology (G.L.J.O., J.A.P., D.A.K., R.Z., I.d.B., M.D.F., G.M.T., A.M.J.M.v.d.M.), Human Genetics (A.D., L.S.V., P.A.C.'tH., A.M.J.M.v.d.M.), Molecular Epidemiology
(M.B., P.E.S.), Radiology (D.A.K.), and Medical Statistics (.J.G.), Leiden University Medical Centre; Department of Biological Psychology (L.L., R.P., D.I.B.), Vrije Universiteit Amsterdam;
Amsterdam Public Health Institute (L.L.); Amsterdam Neuroscience and Amsterdam Public Health (M.B., C.S.T., Y.M., D.I.B., B.W.P.); Department of Psychiatry (M.B., C.S.T., Y.M., B.W.P.),
VU University Medical Centre/GGZ inGeest, Amsterdam; Departments of Epidemiology (A.D., J.L., K.-x.W., N.A., M.A.I., C.M.v.D.) and Neurology (M.A.I.), Erasmus Medical Centre,
Rotterdam; Departments of Genetics (J.F., L.F., C.W.) and Pediatrics (J.F.), University Medical Centre Groningen; Department of Internal Medicine (C.J.H.v.d.K., F.H.M.V., M.M.J.v.G.,
M.T.S., C.D.A.S.) and Heart and Vascular Center (M.T.S.), Maastricht University Medical Centre; CARIM School for Cardiovascular Diseases (C.J.H.v.d.K., M.M.J.v.G., I.C.W.A., M.T.S.,P.C.D.,
C.D.A.S.), Department of Epidemiology (I.C.W.A.), MaCSBio Maastricht Centre for Systems Biology (I.C.W.A.), and Department of Epidemiology (P.C.D.), Maastricht University; De-
partment of Radiology (M.A.I.), Erasmus MC University Medical Centre, Rotterdam; Leiden Academic Centre in Drug Research, Faculty Science (C.M.v.D.), Leiden University; and Centre
for Molecular and Biomolecular Informatics (P.A.C.'tH.), Radboud University Medical Centre Nijmegen, Radboud Institute for Molecular Life Sciences, Nijmegen, the Netherlands.

Go to Neurology.org/N for full disclosures. Funding information and disclosures deemed relevant by the authors, if any, are provided at the end of the article.

The Article Processing Charge was funded by Leiden University.

This is an open access article distributed under the terms of the Creative Commons Attribution-NonCommercial-NoDerivatives License 4.0 (CC BY-NC-ND), which permits downloading

and sharing the work provided it is properly cited. The work cannot be changed in any way or used commercially without permission from the journal. 


\section{Glossary}

apoA1 = apolipoprotein A1; BBMRI = Biobanking and BioMolecular resources Research Infrastructure; BMI = body mass index; CI = confidence interval; ERF = Erasmus Rucphen Family study; ${ }^{1} \mathrm{H}-\mathrm{NMR}$ = proton nuclear magnetic resonance; HDL = high-density lipoprotein; HDL-C = high-density lipoprotein cholesterol; ICHD = International Classification of Headache Disorders; LDL = low-density lipoprotein; LDL-C = low-density lipoprotein cholesterol; LUMINA = Leiden University Migraine Neuro-Analysis; NESDA = Netherlands Study of Depression and Anxiety; NTR = Netherlands Twin Registry; RS = Rotterdam Study; S-HDL-FC = free cholesterol to total lipid ratio in small high-density lipoprotein ratio; TMS = The Maastricht Study; VLDL = very low-density lipoprotein.

Migraine is an episodic brain disorder affecting about $15 \%$ of the general population, occurs 3 times more frequently in women than men, and is ranked as the second most disabling disease worldwide. ${ }^{1-4}$ In one-third of patients, transient focal neurologic symptoms precede the headache (migraine with aura). ${ }^{1}$ Migraine, especially in women, has been linked to an increased risk for cerebrovascular and cardiovascular diseases. ${ }^{5-8}$ Systemic (micro) vascular dysfunction, but not atherosclerosis, ${ }^{9,10}$ has been suggested to be the underlying cause for this association. ${ }^{11,12}$

Previous studies showed elevations of total cholesterol, lowdensity lipoprotein cholesterol (LDL-C), and triglyceride levels, and decreases of high-density lipoprotein cholesterol (HDL-C) levels, to be associated with migraine. ${ }^{13}$ However, results were not consistently replicated due to methodologic variability ${ }^{13}$ emphasizing the need for a systematic approach. High-throughput proton nuclear magnetic resonance $\left({ }^{1} \mathrm{H}\right.$ NMR) allows for the rapid simultaneous identification and quantification of hundreds of metabolite measures in body fluids, providing metabolic profiles in large patient cohorts ${ }^{14}$ that hopefully provide more detailed pathophysiologic insight, beyond the traditional blood-based measurements. Identifying circulating biomarkers might provide insights into molecular signature of migraine, and perhaps its relation with cerebrovascular and cardiovascular disease. ${ }^{12}$

We performed large-scale metabolic profiling of plasma on a ${ }^{1} \mathrm{H}$-NMR platform measuring $>220$ metabolite measures in 8 large Dutch cohorts. ${ }^{14}$ The platform was designed for a detailed assessment of cholesterol measures, triglycerides, creatine, lipids, fatty acids, apolipoproteins, amino acids, glycolysis-related metabolites, and ketone bodies. ${ }^{14}$ We aimed to find circulating biomarkers and functionally related metabolite sets in plasma associated with migraine. Furthermore, we investigated these separately for female or male participants.

\section{Methods}

\section{Study population}

Eight Dutch cohorts, which collaborate in the Dutch Biobanking and BioMolecular resources Research Infrastructure (BBMRI; bbmri.nl/), provided samples: The Leiden University Migraine Neuro-Analysis (LUMINA), ${ }^{15}$ The Netherlands Study of Depression and Anxiety (NESDA-1, NESDA-2), ${ }^{16}$ The Netherlands Twin Registry (NTR), ${ }^{17}$ The Erasmus Rucphen Family study (ERF) ${ }^{18,19}$ The Rotterdam Study (RS), ${ }^{20}$ The Maastricht Study (TMS), ${ }^{21}$ and LifeLines. ${ }^{22,23}$ These cohorts include population-based cohorts (NTR, ERF, RS, and LifeLines), webbased (clinic-based) (LUMINA) cohorts, and mixed clinic- and population-based cohorts (NESDA-1, NESDA-2, and TMS). Participants were unrelated, except for NTR and ERF participants. NTR participants included twins, their parents, siblings, and spouses. ERF participants originated from a genetically isolated population in the southwest of the Netherlands. Cases were patients diagnosed with migraine. Probable migraine cases were not included. The control group consisted of participants negative for (probable) migraine. Apart from probable migraine patients, no participants were excluded. Information on migraine symptomatology, used for migraine assessment, was collected by means of surveys based on the International Classification of Headache Disorders (ICHD) criteria (NESDA, NTR, and TMS), ${ }^{24}$ self-reported only (LifeLines), or a combination of questionnaires based on the ICHD criteria and a follow-up (telephone) interview (LUMINA, ERF, and RS). ${ }^{24,25}$ For details regarding the cohorts, migraine assessments, other relevant disorders, and sampling procedures, see e-Methods (doi.org/10.5061/dryad.p698mn7). All blood samples were measured essentially in one batch in 2014, with the exception of part of the samples from NESDA (the NESDA-2 samples), which were analyzed a few months later.

\section{Standard protocol approvals, registrations, and patient consents}

All participants of the respective cohorts provided written informed consent. The study was approved by the local ethics committees of each study.

\section{Metabolite quantification}

Metabolites were quantified from EDTA plasma samples of 10,174 individuals (after quality control, 10,153 samples remained), analyzed using the same high-throughput ${ }^{1} \mathrm{H}-\mathrm{NMR}$ metabolomics platform (Nightingale Health Ltd., Helsinki, Finland; nightingalehealth.com/). ${ }^{14}$ This platform provides simultaneous quantification of 147 individual metabolites and 79 metabolite ratios; for example, routine lipids, lipoprotein subclass profiling with lipid concentrations within 14 subclasses, esterified fatty acid composition, and various low-molecular metabolites including amino acids, ketone bodies, and gluconeogenesis-related metabolites in molar concentration units. Details of the experimentation and applications of the NMR metabolomics platform have been described previously. ${ }^{14}$ 


\section{Data preprocessing}

The study flowchart is presented in figure 1. Metabolite measures that failed quality control (in particular glutamine, pyruvate, glycerol, $\beta$-hydroxybutyrate, and acetate) were excluded from the analysis. Metabolite measures with $>10 \%$ missing values were excluded entirely. The final set of metabolite measures comprised 146 metabolites and 79 ratios, totaling 225 metabolite measures. Second, outliers ( $>5$ SD) were removed in concordance with previous research in this field. ${ }^{26}$ Third, metabolite measurements were raised by 1 to allow log-transformation. Thereafter all metabolite values were log-transformed and scaled to approximate normality using a $z$-transformation prior to the analyses of each cohort. This process was conducted using R 3.3.2 (R Foundation for Statistical Computing, Vienna, Austria).

\section{Single-metabolite logistic regression}

For each metabolite measure separately, logistic regression was performed with the metabolite measure, age at blood draw, and sex as independent variables, and migraine status as dependent variable. The obtained estimates and standard errors for the metabolite measures were used in the

Figure 1 Study flowchart

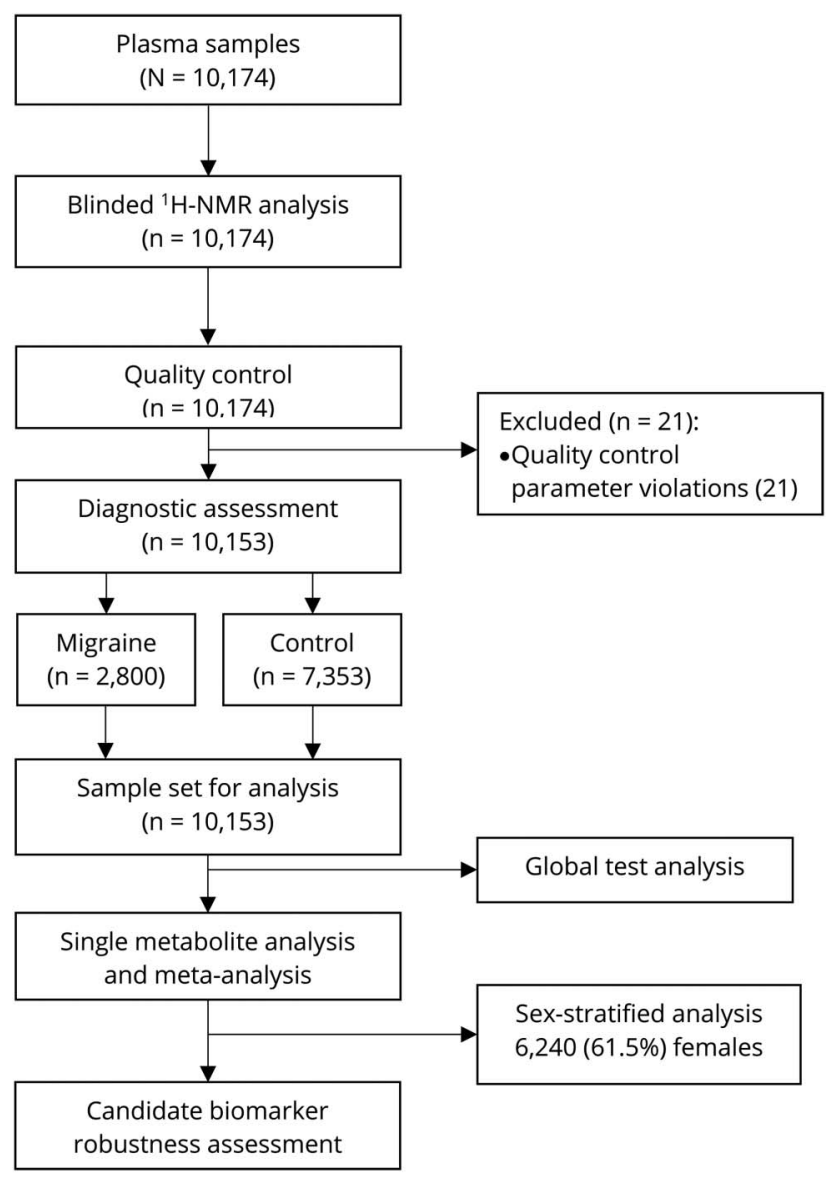

Determination of the sample set used for data analysis and the different data analysis approaches performed in the current study. ${ }^{1} \mathrm{H}-\mathrm{NMR}=$ proton nuclear magnetic resonance. subsequent random-effects meta-analysis. A random-effects model was chosen to account for possible heterogeneity due to differences in migraine assessment, sample processing, and sample collection between cohorts. Heterogeneity was assessed using the $I^{2}$ statistic and by visual inspection of forest plots. The family-wise error rate (the probability of making at least one type I error [false-positive] in a set of measures) was controlled at $5 \%$ with the Holm procedure (Holm-Bonferroni). ${ }^{27}$ This multiple testing correction procedure was used because it is appropriate in case of strongly correlated measures, as is the case for our 225 metabolite measures. We investigated the influence of familial relatedness on metabolite levels in NTR and ERF using Pearson correlation analysis, but the effect of heritability on metabolite measure estimates (NTR $r=0.984$ and ERF $r=0.838)$ and $p$ values (NTR $r=$ 0.972 and ERF $r=0.702$ ) was negligible (figure e-1; doi.org/ 10.5061/dryad.p698mn7). Therefore, we did not include relatedness in the model. Meta-analyses were conducted with the meta software package for R 3.3.2.

\section{Influence of other covariates}

First, we independently assessed, within LUMINA and NESDA, the influence of depression, smoking, fasting status, body mass index (BMI), and lipid-lowering medication usage on the metabolite levels of the candidate biomarkers identified in the single-metabolite logistic regression, using stratification plots. LUMINA and NESDA cohorts were selected, because the catalogue of covariates was most complete for these cohorts and because the current migraine assessment (LUMINA) and depression assessment (NESDA) were most accurate and detailed. Furthermore, NESDA was the only cohort that was measured in 2 separate batches. BMI and lipid-lowering medication usage showed to be of influence on the candidate biomarkers and were added to the singlemetabolite logistic regression model in all 8 cohorts. Subsequently, meta-analyses were repeated.

\section{Stability measure}

We studied the stability of metabolite measures in LUMINA participants $(n=41)$ that were sampled twice and measured in the same batch on the ${ }^{1} \mathrm{H}$-NMR platform. ${ }^{14}$ For these participants, time between blood draws ranged from 15 days to almost 4 years (average $833 \pm 434$ days). To investigate correlation between measurements and assess the effect of time on metabolite levels, the absolute values on the first and second measurement and the value difference between the paired measurements vs the days between the measurements was computed and analyzed with Pearson correlation analysis. $p$ Values $<0.05$ were regarded as statistically significant. Analyses were performed using SPSS 23.0 (SPSS Inc., IBM, Armonk, NY) and GraphPad Prism version 7.02 for Windows (GraphPad Software, La Jolla, CA).

\section{Sex-stratified analysis}

In order to ascertain if the association of metabolites with migraine status may be different between male and female participants, we performed analyses stratified for sex in 
accordance with the aforementioned single-metabolite logistic regression and random-effects meta-analysis model with family-wise error rate at 5\% controlled using the Holm procedure (Holm-Bonferroni). ${ }^{27}$

\section{Global test analysis}

Associations of predefined sets of related metabolites with migraine status were tested with the global test framework, ${ }^{28,29}$ adjusted for sex, age at blood draw, BMI, and lipid-lowering medication usage. The global test is aimed at associations between particular sets of (functionally) related metabolites and migraine status and does not test the direction of the association, that is, whether sets of metabolites are upregulated or downregulated. Metabolites were assigned to 23 different groups (tables e-1 and e-2; doi.org/10.5061/dryad. p698mn7) in agreement with the Kyoto Encyclopedia of Genes and Genomes pathways and in accordance with a previous pathway analysis conducted with the same NMR platform. ${ }^{30}$ The test statistics for the separate cohorts ( $p$ values) from the global test were meta-analyzed using the Fisher combination method. ${ }^{31} p$ Values $<0.05$ after HolmBonferroni correction were considered statistically significant. Statistical analyses were conducted using the global test 5.30.0 software package for $\mathrm{R}$ 3.3.2.

\section{Data availability}

The data that support the findings of this study will be available in the BBMRI-omics atlas (bbmri.researchlumc.nl/ atlas) and in the depository (datadryad.org/review?doi=doi: 10.5061/dryad.p698mn7).

\section{Results}

\section{Study population}

Reliable quantification of 146 blood plasma metabolites and 79 metabolite ratios were available for 10,153 participants from 8 different cohorts: 2,800 migraine patients $(80.6 \%$ female) and 7,353 controls ( $54.1 \%$ female) (see study flowchart [figure 1]). Clinical characteristics from all cohorts are shown in table 1 .

\section{Single-metabolite logistic regression}

To identify potential metabolite biomarkers associated with migraine status, we performed a separate logistic regression for each metabolite measure in each cohort (table e-3; doi.org/10. 5061/dryad.p698mn7). Corresponding results were used in a random-effects meta-analysis. Migraine was associated with decreased apolipoprotein A1 levels (apoA1, an apoprotein with specific association with high-density lipoprotein [HDL]) ( $\beta-0.10,95 \%$ confidence interval $[\mathrm{CI}]-0.16,-0.05$, adjusted $p=0.029)$ and decreased free cholesterol to total lipid ratio in small HDL (S-HDL-FC ratio; $\beta-0.10,95 \% \mathrm{CI}-0.15,-0.05$, adjusted $p=0.029$ ) (figure 2 ). Heterogeneity between cohorts was minimal with $I^{2}=0 \%$ for both metabolite measures. A $\beta$ of -0.10 translates to an odds ratio for having migraine of 1.22 when comparing an individual with a typical low metabolite score $(z=-1$ or 1 SD below average) and an individual with a typical high metabolite score $(\mathrm{z}=1$ or $1 \mathrm{SD}$ above average).
Other HDL particle measures (XL-HDL- [C, CE, FC, L, P, and PL], L-HDL-[C, CE, FC, L, P, PL, and TG], total cholesterol in HDL and HDL2, the mean diameter for HDL particles, and the total cholesterol to total lipids ratio in very large HDL) were also reduced in migraine, but failed to reach significance after correction for multiple comparisons (table e-4; doi.org/ 10.5061/dryad.p698mn7). Despite the high negative correlation between $\mathrm{HDL}$ and very low-density lipoprotein (VLDL) or low-density lipoprotein (LDL) measures, only a few associations with LDL or VLDL measures were found nominally significant and none remained significant after correction for multiple comparisons.

\section{Candidate biomarker robustness assessment}

Next, we assessed the influence of smoking, fasting status, depression, lipid-lowering medication usage, and BMI (figures e-2-e-6; doi.org/10.5061/dryad.p698mn7) on apoA1 levels and the S-HDL-FC ratio in the LUMINA and NESDA cohorts. Small effects of lipid-lowering medication usage and BMI on apoA1 and S-HDL-FC ratio plasma levels were identified. Other covariates did not influence these levels. For all cohorts, BMI and lipid-lowering medication usage were subsequently added to our model. The expanded model revealed that a decreased apoA1 level $(\beta-0.092$, 95\% CI $-0.15,-0.04)$ and S-HDL-FC ratio $(\beta-0.068,95 \% \mathrm{CI}-0.12$, -0.02 ) were still associated (uncorrected $p$ values 0.0010 and 0.0095 ) with migraine. To further support the robustness of the candidate biomarkers, correlation analyses using 82 samples from 41 participants, acquired on 2 occasions (833 \pm 434 days apart), revealed particularly stable results between measurements in the same individual patient for apoA1 $(r=0.859)$ and to a lesser extent for S-HDL-FC ratio $(r=0.497)$ (figure e-7; doi.org/10.5061/ dryad.p698mn7).

\section{Sex-stratified analysis}

Given the preponderance of females among migraine patients, we searched for possible differences in the metabolite profile associated with migraine between male and female participants (figure 3). ApoA1 levels were significantly associated with migraine in male participants, with smaller effects, but in similar direction, in female participants. Furthermore, the apoB/apoA1 ratio was significantly higher in female migraineurs compared to female controls. The S-HDL-FC ratio (table e-5; doi.org/10.5061/dryad.p698mn7) was negatively associated with migraine in female participants, but failed to reach significance after correction for multiple testing. In male participants, no apparent relation was identified for the S-HDL-FC ratio. Associations with lower medium and large HDL measures (L-HDL-[C, CE, FC, L, P, and PL]) were significant in female participants, with a similar finding in male participants, although not significant. Interestingly, in male participants, lower omega-3 fatty acids $(p=0.033)$ were associated with migraine, an association not seen in female participants. Clinical characteristics from all cohorts stratified for sex and the sex-stratified meta-analysis are shown in table 1 . 
Table 1 Baseline characteristics of the study populations

\begin{tabular}{|c|c|c|c|c|c|c|c|c|c|c|c|c|c|c|c|c|}
\hline & \multicolumn{4}{|c|}{ LUMINA $(n=408)$} & \multicolumn{4}{|c|}{ NESDA-1 $(n=1,082)$} & \multicolumn{4}{|c|}{ NTR $(n=2,873)$} & \multicolumn{4}{|c|}{$\operatorname{ERF}(n=1,413)$} \\
\hline & \multicolumn{2}{|c|}{ Cases $(n=317)$} & \multicolumn{2}{|c|}{ Controls $(n=91)$} & \multicolumn{2}{|c|}{ Cases $(n=276)$} & \multicolumn{2}{|c|}{ Controls $(n=806)$} & \multicolumn{2}{|c|}{ Cases $(n=1,360)$} & \multicolumn{2}{|c|}{ Controls $(n=1,513)$} & \multicolumn{2}{|c|}{ Cases $(n=178)$} & \multicolumn{2}{|c|}{ Controls $(n=1,235)$} \\
\hline & M & $\mathbf{F}$ & M & $\mathbf{F}$ & M & $\mathbf{F}$ & M & $\mathbf{F}$ & M & $\mathbf{F}$ & M & $\mathbf{F}$ & M & $\mathbf{F}$ & M & $\mathbf{F}$ \\
\hline Total, $\mathbf{n}$ & 105 & 212 & 47 & 44 & 48 & 228 & 353 & 453 & 217 & 1143 & 571 & 942 & 39 & 139 & 598 & 637 \\
\hline $\begin{array}{l}\text { Age, } y, \text { mean } \pm \\
\text { SD }\end{array}$ & $\begin{array}{l}44.6 \pm \\
13.0\end{array}$ & $\begin{array}{l}42.4 \pm \\
12.1\end{array}$ & $\begin{array}{l}42.1 \pm \\
13.9\end{array}$ & $\begin{array}{l}36.2 \pm \\
14.0\end{array}$ & $\begin{array}{l}41.7= \\
11.6\end{array}$ & $\begin{array}{l}39.7 \pm \\
11.3\end{array}$ & $\begin{array}{l}44.1 \pm \\
12.8\end{array}$ & $\begin{array}{l}41.9 \pm \\
13.8\end{array}$ & $\begin{array}{l}44.5 \pm \\
14.0\end{array}$ & $\begin{array}{l}41.4 \pm \\
12.7\end{array}$ & $\begin{array}{l}40.4 \pm \\
14.4\end{array}$ & $\begin{array}{l}39.3 \pm \\
13.6\end{array}$ & $\begin{array}{l}46.6 \pm \\
11.9\end{array}$ & $\begin{array}{l}45.8 \pm \\
12.3\end{array}$ & $\begin{array}{l}48.8 \pm \\
14.0\end{array}$ & $\begin{array}{l}48.3 \pm \\
14.5\end{array}$ \\
\hline $\begin{array}{l}\mathrm{BMI}, \mathrm{kg} / \mathrm{m}^{2} \\
\text { mean } \pm \mathrm{SD}\end{array}$ & $\begin{array}{l}24.5 \pm \\
2.6\end{array}$ & $\begin{array}{l}23.9 \pm \\
3.8\end{array}$ & $\begin{array}{l}24.2 \pm \\
2.7\end{array}$ & $\begin{array}{l}23.4 \pm \\
3.4\end{array}$ & $\begin{array}{l}26.5 \\
5.1\end{array}$ & $\begin{array}{l}25.5 \pm \\
5.2\end{array}$ & $\begin{array}{l}26.1 \pm \\
4.5\end{array}$ & $\begin{array}{l}25.1 \pm \\
5.0\end{array}$ & $\begin{array}{l}25.2 \pm \\
3.9\end{array}$ & $\begin{array}{l}24.8 \pm \\
4.5\end{array}$ & $\begin{array}{l}24.9 \pm \\
3.4\end{array}$ & $\begin{array}{l}23.9 \pm \\
3.9\end{array}$ & $\begin{array}{l}28.0 \pm \\
5.5\end{array}$ & $\begin{array}{l}27.2 \pm \\
5.6\end{array}$ & $\begin{array}{l}27.3 \pm \\
4.3\end{array}$ & $\begin{array}{l}26.4 \pm \\
4.9\end{array}$ \\
\hline \multirow[t]{4}{*}{ LLMU, $\mathbf{n}$} & 1 & 5 & 2 & 0 & 8 & 12 & 40 & 20 & 22 & 37 & 37 & 41 & 3 & 16 & 73 & 64 \\
\hline & \multicolumn{4}{|c|}{$\operatorname{RS}(n=1,425)$} & \multicolumn{4}{|c|}{ TMS $(n=687)$} & \multicolumn{4}{|c|}{ LifeLines $(n=1,319)$} & \multicolumn{4}{|c|}{ NESDA-2 $(n=946)$} \\
\hline & \multicolumn{2}{|c|}{ Cases $(n=173)$} & \multicolumn{2}{|c|}{ Controls $(n=1,252)$} & \multicolumn{2}{|c|}{ Cases $(n=79)$} & \multicolumn{2}{|c|}{ Controls $(n=608)$} & \multicolumn{2}{|c|}{ Cases $(n=249)$} & \multicolumn{2}{|c|}{ Controls $(n=1,070)$} & \multicolumn{2}{|c|}{ Cases $(n=168)$} & \multicolumn{2}{|c|}{ Controls $(n=778)$} \\
\hline & M & $\mathbf{F}$ & M & $\mathbf{F}$ & M & $\mathbf{F}$ & M & $\mathbf{F}$ & M & $\mathbf{F}$ & M & $\mathbf{F}$ & M & $\mathbf{F}$ & M & $\mathbf{F}$ \\
\hline Total, $\mathbf{n}$ & 29 & 144 & 556 & 696 & 27 & 52 & 458 & 150 & 49 & 200 & 504 & 566 & 27 & 141 & 285 & 493 \\
\hline $\begin{array}{l}\text { Age, } y \\
\text { mean } \pm \text { SD }\end{array}$ & $\begin{array}{l}77.4 \pm \\
4.2\end{array}$ & $\begin{array}{l}79.3 \pm \\
5.1\end{array}$ & $\begin{array}{l}79.3 \pm \\
4.6\end{array}$ & $\begin{array}{l}79.5 \pm \\
4.9\end{array}$ & $\begin{array}{l}59.2 \pm \\
8.5\end{array}$ & $\begin{array}{l}61.5 \pm \\
7.1\end{array}$ & $\begin{array}{l}63.2 \pm \\
7.3\end{array}$ & $\begin{array}{l}61.8 \pm \\
8.1\end{array}$ & $\begin{array}{l}44.1 \pm \\
11.1\end{array}$ & $\begin{array}{l}43.3 \pm \\
12.3\end{array}$ & $\begin{array}{l}44.8 \pm \\
14.1\end{array}$ & $\begin{array}{l}43.9 \pm \\
13.8\end{array}$ & $\begin{array}{l}39.8 \pm \\
9.8\end{array}$ & $\begin{array}{l}41.8 \pm \\
12.4\end{array}$ & $\begin{array}{l}44.7 \pm \\
13.5\end{array}$ & $\begin{array}{l}42.7 \pm \\
13.6\end{array}$ \\
\hline $\begin{array}{l}\mathrm{BMI}, \mathrm{kg} / \mathrm{m}^{2} \\
\text { mean } \pm \mathrm{SD}\end{array}$ & $\begin{array}{l}26.9 \pm \\
3.0\end{array}$ & $\begin{array}{l}27.6 \pm \\
4.6\end{array}$ & $\begin{array}{l}27.0 \pm \\
3.3\end{array}$ & $\begin{array}{l}27.8 \pm \\
4.3\end{array}$ & $\begin{array}{l}28.0 \pm \\
3.4\end{array}$ & $\begin{array}{l}30.0 \pm \\
5.8\end{array}$ & $\begin{array}{l}29.6 \pm \\
4.7\end{array}$ & $\begin{array}{l}30.3 \pm \\
5.5\end{array}$ & $\begin{array}{l}26.1 \pm \\
3.3\end{array}$ & $\begin{array}{l}25.6 \pm \\
5.2\end{array}$ & $\begin{array}{l}25.3 \pm \\
3.4\end{array}$ & $\begin{array}{l}24.8 \pm \\
4.2\end{array}$ & $\begin{array}{l}26.7 \pm \\
5.2\end{array}$ & $\begin{array}{l}24.8 \pm \\
4.7\end{array}$ & $\begin{array}{l}25.9 \pm \\
4.2\end{array}$ & $\begin{array}{l}24.9 \pm \\
4.7\end{array}$ \\
\hline LLMU, n & 8 & 31 & 142 & 153 & 21 & 31 & 335 & 113 & 0 & 8 & 29 & 20 & 0 & 4 & 32 & 36 \\
\hline
\end{tabular}

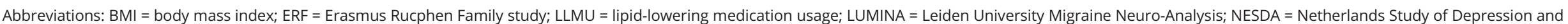
Anxiety; NTR = Netherlands Twin Registry; RS = Rotterdam Study; TMS = The Maastricht Study 
Figure 2 Forest plots of candidate migraine biomarkers apolipoprotein A1 (apoA1) and the free cholesterol to total lipid ratio in small high-density lipoprotein ratio (S-HDL-FC)

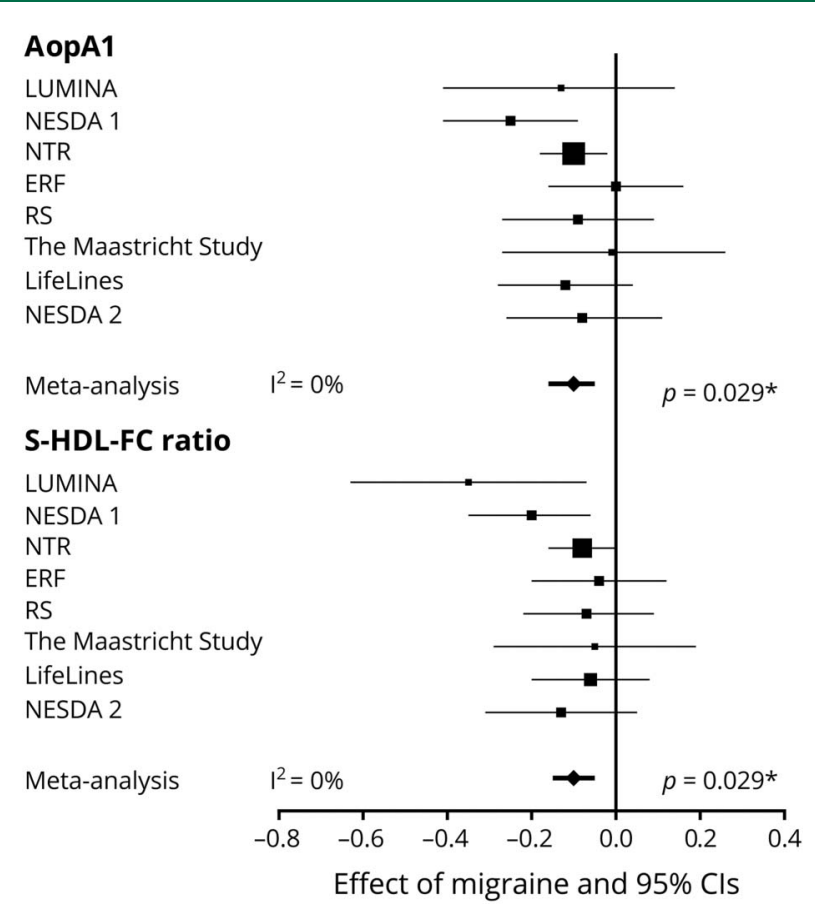

Associations with migraine in random-effects meta-analyses. The effect sizes and 95\% confidence intervals (Cls) for apoA1 and S-HDL-FC are presented per cohort and in a random-effects meta-analysis. Values from logistic regression with metabolite levels, sex, and age as independent variables and migraine status as dependent variable. Error bars denote $95 \%$ $\mathrm{Cls}$. To facilitate the interpretation of the effect sizes ( $\beta$ coefficients), we calculated the odds ratio (OR) for having migraine for a typical low metabolite score ( $z$ score $=-1,1$ SD below average) and a typical high metabolite score: $\beta-0.10$, OR 1.22; $\beta-0.20$, OR 1.49; $\beta-0.30$, OR 1.82; $\beta-0.40$, OR $2.22 ; \beta$ -0.50 , OR 2.72. * $p$ Values after Holm-Bonferroni $(p<0.0002)$ multiple testing correction. ERF = Erasmus Rucphen Family study; $l^{2}=$ measure of heterogeneity; LUMINA = Leiden University Migraine Neuro-Analysis; NESDA = Netherlands Study of Depression and Anxiety 1 and 2; NTR = Netherlands Twin Registry; RS = Rotterdam Study

\section{Global test analysis}

To detect if migraine status was associated with particular sets of (functionally) related metabolites, we tested the association of 23 different predefined sets of metabolites with migraine status using the global test. The global test does not evaluate each metabolite measure individually, but tests whether the levels of a group of metabolites are associated with an outcome (in this case, migraine status). We controlled for the same covariates as in the logistic regression per metabolite. The global test was first applied per cohort, after which the $p$ values were combined in a meta-analysis using the Fisher method (figure 4 and table 2). The global test analysis confirmed the association of HDL-associated metabolites with migraine, already apparent from the single metabolite analysis, with large clusters of medium $(\mathrm{M}-)$ to very large $(\mathrm{XL}-)$ HDL subclasses generally associated with migraine status across the majority of cohorts (figure e-8; doi.org/10.5061/dryad. p698mn7). Interestingly, no other lipoprotein classes were associated with migraine. Somewhat surprisingly, the
Figure 3 Sex-stratified metabolite associations with migraine

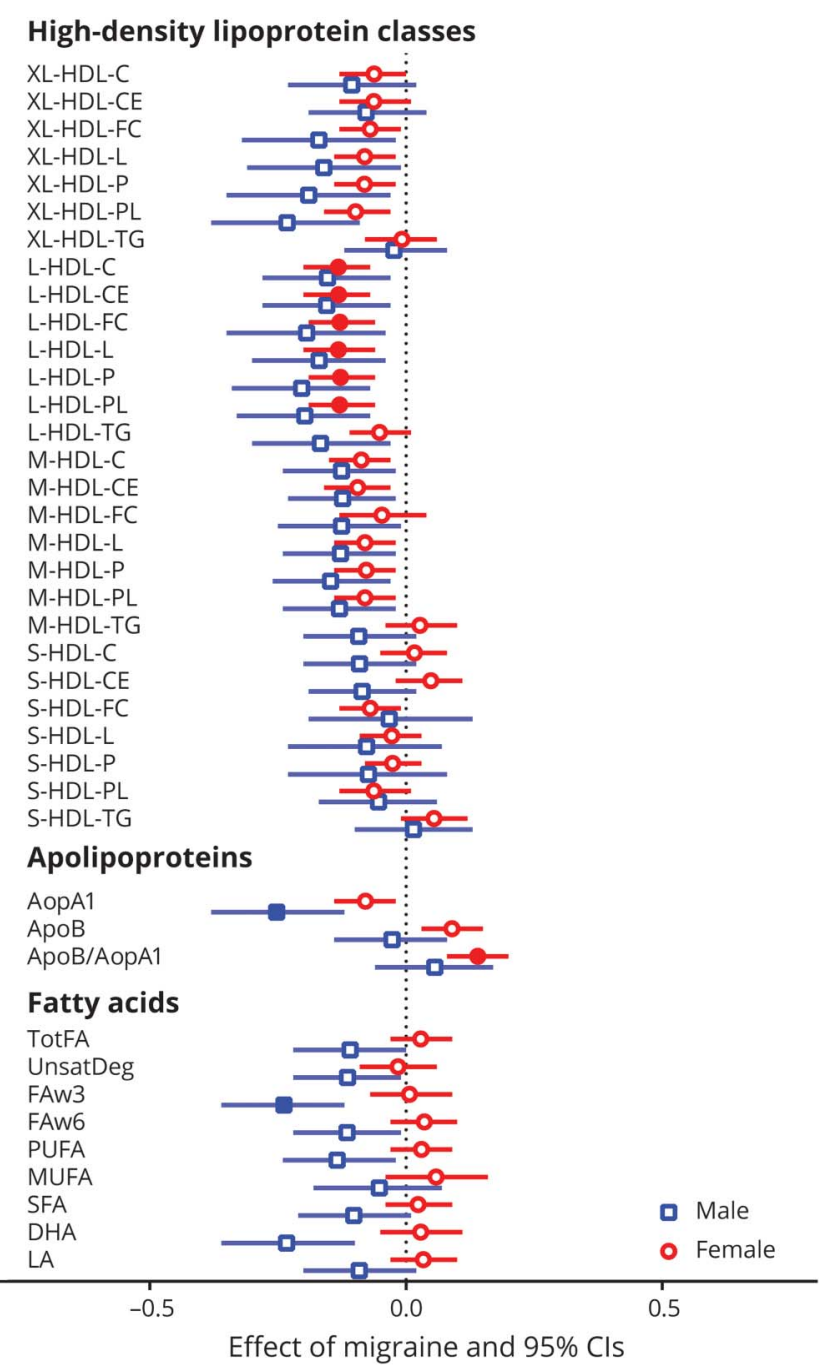

Metabolite associations with migraine in male (blue squares) and female (red circles) participants in a random-effects meta-analysis comprised of 8 cohorts. The effect sizes and 95\% confidence intervals (Cls) are shown. Values are from logistic regression with metabolite levels, sex, age, body mass index, and lipid-lowering medication usage as independent variables and migraine status as dependent variable. Error bars denote $95 \% \mathrm{Cls}$, filled squares (male participants ) or circles (female participants) indicate significance after Holm-Bonferroni $(p<0.0002)$ multiple testing correction. All other metabolite classes without significant metabolites after Holm-Bonferroni correction as well as $I^{2}$ values can be found in table e-5 (doi.org/10. $5061 /$ dryad.p698mn7). To facilitate the interpretation of the effect sizes ( $\beta$ coefficients), we calculated the odds ratio (OR) for having migraine for a typical low metabolite score ( $z$ score $=-1,1$ SD below average) and a typical high metabolite score: $\beta-0.10$, OR 1.22; $\beta-0.20$, OR 1.49; $\beta-0.30$, OR 1.82; $\beta$ -0.40 , OR 2.22; $\beta-0.50$, OR 2.72. All metabolite abbreviations can be found in tables e-1 and e-2 (doi.org/10.5061/dryad.p698mn7).

metabolism of valine, leucine, and isoleucine was significantly associated with migraine, and not in line with the findings from the single-metabolite analyses. This is a falsepositive result, obtained because this meta-analysis method is based on nondirectional $p$ values, and may provide a significant $p$ value even when the direction of change is not consistent between cohorts, as is the case for these branched chain amino acids. 


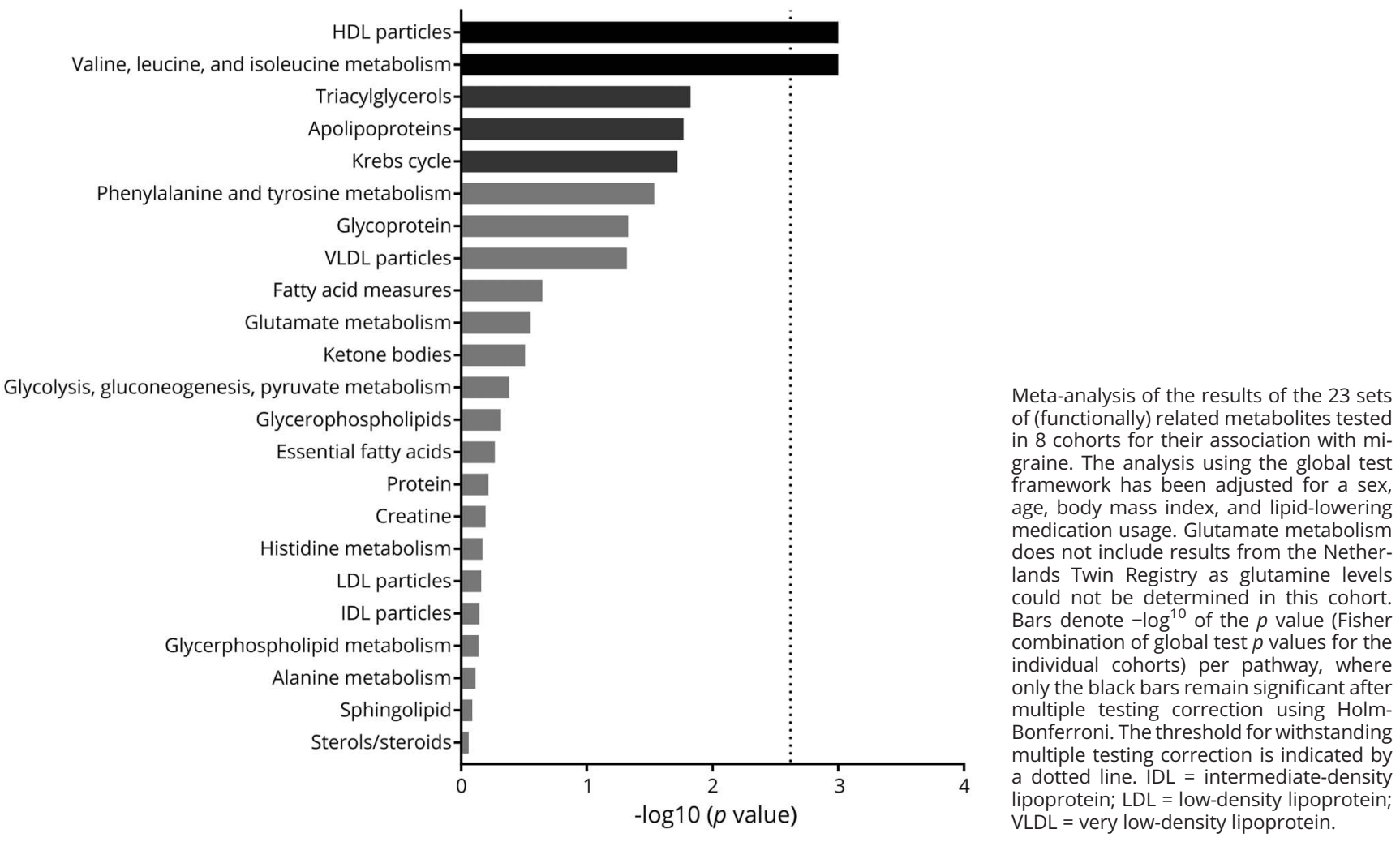

\section{Discussion}

We performed high-throughput ${ }^{1} \mathrm{H}-\mathrm{NMR}$ metabolite profiling of 225 metabolite measures in plasma samples from 8 Dutch cohorts and identified a consistent association between migraine and decreased HDL levels. We identified 2 circulating candidate migraine biomarkers, which are both related to HDL status: a decreased level of apoA1 (an apoprotein with a specific association with HDL) and a decreased S-HDL-FC ratio (the free cholesterol to total lipid ratio in small HDL). In addition, fatty acids of the omega- 3 class were shown to be associated with migraine, but only in male participants.

Dyslipidemia and migraine have been extensively studied because of the comorbidity of cerebrovascular and cardiovascular disease and migraine, with the strongest associations in young women without elevated conventional cardiovascular risk profiles. ${ }^{5-8,13}$ Large population-based studies suggested elevated total cholesterol, LDL-C, or triglycerides, and decreased levels of HDL-C, in migraine. ${ }^{5-8,13}$ However, earlier results were conflicting ${ }^{13}$ due to cohort variability and measurement of crude lipoprotein levels, ${ }^{5-8,13}$ or failed to detect differences in apoA1 levels, possibly due to lack of power. ${ }^{32,33}$ Notably, the sufficiently powered Women's Health Study observed a nonsignificant effect with decreased apoA1 levels in 5,087 female participants with a history of migraine (total population 27,626 , mean age 54.7 years).$^{34} \mathrm{~A}$ more prominent association between migraine and apoA1 in men compared to women, and lower mean age in the current study, might explain the difference between the studies. To the best of our knowledge, lower omega- 3 fatty acid levels have not been reported in migraine. Of note, omega- 3 fatty acid supplements, due to their anti-inflammatory action, have been investigated in migraine attack prevention. ${ }^{35} \mathrm{~A}$ recent metaanalysis found no apparent reduction in headache frequency after omega-3 fatty acid supplementation; however, a significant reduction in headache duration was found across studies. ${ }^{35}$

HDL subclasses are composed of proteins and lipids, each roughly representing $50 \%$ of the total mass of HDL. Major proteins are apoA1 (70\%) and apoA2 (20\%) together with proteins such as apoA4, apoE, apoJ, haptoglobin, paraoxanase, a2-macroglobulin, and lecithin cholesterol acyltransferase. ${ }^{36}$ These proteins contribute to various functions of HDL, including mediating the reverse cholesterol transport pathway and antioxidative, anti-inflammatory, and antithrombotic effects. ${ }^{37}$ Combining the different analyses conducted, we identified an association between deceased apoA1 level and S-HDL-FC ratio and migraine together with decreased levels of medium to very large HDL measures, in the absence of clear LDL, intermediatedensity lipoprotein, or VLDL involvement. Thus, the observed profiles suggest that migraine is associated with alterations in specific HDL functions but not with a general dyslipidemia profile characteristic for cardiovascular conditions.

Although this biomarker discovery study was not aimed to unravel pathophysiologic mechanisms, several hypotheses 
Table 2 Cohort results of global test analysis and Fisher combination method

\begin{tabular}{|c|c|c|c|c|c|c|c|c|c|c|}
\hline & $\begin{array}{l}\text { LUMINA, } \\
p \text { value }\end{array}$ & $\begin{array}{l}\text { NESDA-1, } \\
p \text { value }\end{array}$ & $\begin{array}{l}\text { NTR, } \\
p \text { value }\end{array}$ & $\begin{array}{l}\text { ERF, } \\
p \text { value }\end{array}$ & $\begin{array}{l}\mathrm{RS} \text {, } \\
p \text { value }\end{array}$ & $\begin{array}{l}\text { TMS, } \\
p \text { value }\end{array}$ & $\begin{array}{l}\text { Lifelines, } \\
p \text { value }\end{array}$ & $\begin{array}{l}\text { NESDA-2, } \\
p \text { value }\end{array}$ & $\begin{array}{l}\text { Fisher } \\
\text { method }\end{array}$ & $\begin{array}{l}\text { H-B corrected } \\
p \text { value }\end{array}$ \\
\hline HDL particles & 0.059 & 0.0091 & 0.047 & 0.052 & 0.228 & 0.372 & 0.059 & 0.448 & 0.00098 & 0.022 \\
\hline Valine, leucine, isoleucine metabolism & 0.018 & 0.068 & 0.246 & 0.108 & 0.964 & 0.00014 & 0.743 & 0.766 & 0.00088 & 0.020 \\
\hline Triacylglycerols & 0.099 & 0.507 & 0.567 & 0.225 & 0.236 & 0.473 & 0.00088 & 0.374 & 0.015 & 0.325 \\
\hline Apolipoproteins & 0.059 & 0.023 & 0.133 & 0.056 & 0.570 & 0.609 & 0.123 & 0.631 & 0.017 & 0.336 \\
\hline Krebs cycle & 0.118 & 0.254 & 0.066 & 0.0041 & 0.399 & 0.445 & 0.382 & 0.591 & 0.019 & 0.356 \\
\hline Phenylalanine and tyrosine metabolism & 0.0036 & 0.795 & 0.429 & 0.039 & 0.315 & 0.271 & 0.400 & 0.436 & 0.029 & 0.524 \\
\hline Glycoprotein & 0.015 & 0.115 & 0.415 & 0.484 & 0.849 & 0.104 & 0.966 & 0.059 & 0.047 & 0.804 \\
\hline VLDL particles & 0.062 & 0.406 & 0.396 & 0.481 & 0.461 & 0.538 & 0.0050 & 0.295 & 0.048 & 0.804 \\
\hline Fatty acid measures & 0.283 & 0.271 & 0.153 & 0.294 & 0.607 & 0.735 & 0.057 & 0.544 & 0.226 & 1.000 \\
\hline Glutamate metabolism ${ }^{a}$ & 0.190 & 0.069 & NA & 0.369 & 0.478 & 0.706 & 0.259 & 0.601 & 0.280 & 1.000 \\
\hline Ketone bodies & 0.279 & 0.035 & 0.806 & 0.568 & 0.213 & 0.768 & 0.290 & 0.523 & 0.310 & 1.000 \\
\hline $\begin{array}{l}\text { Glycolysis, gluconeogenesis, pyruvate } \\
\text { metabolism }\end{array}$ & 0.826 & 0.820 & 0.182 & 0.045 & 0.899 & 0.093 & 0.586 & 0.927 & 0.413 & 1.000 \\
\hline Glycerophospholipids & 0.660 & 0.166 & 0.068 & 0.645 & 0.827 & 0.521 & 0.404 & 0.490 & 0.482 & 1.000 \\
\hline Essential fatty acids & 0.608 & 0.045 & 0.663 & 0.416 & 0.483 & 0.775 & 0.645 & 0.334 & 0.539 & 1.000 \\
\hline Protein & 0.639 & 0.777 & 0.086 & 0.591 & 0.179 & 0.451 & 0.588 & 0.800 & 0.606 & 1.000 \\
\hline Creatine & 0.617 & 0.994 & 0.352 & 0.068 & 0.194 & 0.528 & 0.966 & 0.822 & 0.639 & 1.000 \\
\hline Histidine metabolism & 0.957 & 0.873 & 0.549 & 0.520 & 0.987 & 0.330 & 0.605 & 0.033 & 0.676 & 1.000 \\
\hline LDL particles & 0.205 & 0.378 & 0.775 & 0.122 & 0.972 & 0.866 & 0.443 & 0.626 & 0.691 & 1.000 \\
\hline IDL particles & 0.163 & 0.376 & 0.673 & 0.292 & 0.900 & 0.925 & 0.352 & 0.576 & 0.716 & 1.000 \\
\hline Glycerolipid metabolism & 0.536 & 0.244 & 0.237 & 0.426 & 0.658 & 0.622 & 0.705 & 0.563 & 0.724 & 1.000 \\
\hline Alanine metabolism & 0.408 & 0.588 & 0.812 & 0.353 & 0.906 & 0.130 & 0.590 & 0.633 & 0.770 & 1.000 \\
\hline Sphingolipids & 0.164 & 0.383 & 0.306 & 0.909 & 0.550 & 0.776 & 0.781 & 0.736 & 0.816 & 1.000 \\
\hline Sterols/steroids & 0.232 & 0.428 & 0.965 & 0.268 & 0.922 & 0.880 & 0.343 & 0.981 & 0.871 & 1.000 \\
\hline
\end{tabular}

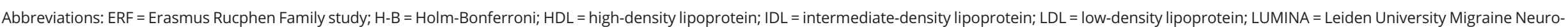

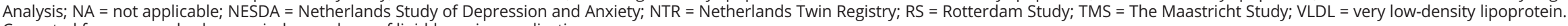

Corrected for age, sex, body mass index, and use of lipid-lowering medication.

a Determined without NTR due to nonquantified glutamine measurements. 
regarding pathophysiological mechanisms emerge from the study. First, our findings provide some biochemical evidence for a link with endothelium dysfunction in migraine as $\mathrm{HDL}$ with its antioxidative, anti-inflammatory, and antithrombotic effects plays a role in endothelial function. ${ }^{36-38}$ Interestingly, omega-3 fatty acids, which showed decreased levels associated with migraine in male participants, have also been shown to be vasoprotective and have been deemed to generate antiinflammatory resolvins. ${ }^{39}$ It is at this point, however, only speculation whether reduced protective actions of HDL and omega-3 through endothelial dysfunction may explain the association with migraine. Second, it has been suggested that omega-3 fatty acids and certain HDL subclasses can travel across the blood-brain barrier, which may have effects on a neuronal level. ${ }^{40-42}$ Third, that omega-3 fatty acids are associated with migraine exclusively in male participants may suggest distinct sex-specific mechanisms. However, this might also be due to differences in omega-3-rich food consumption $^{43}$ and requires further specific investigation.

The strengths of this study are the large sample size $(>10,000$ participants) and extensive metabolic profiling (225 metabolite measures) to identify candidate biochemical biomarkers for migraine. Furthermore, similar methods (EDTA samples, ${ }^{1} \mathrm{H}$-NMR platform, and facility) were used across cohorts. A possible limitation of the study is that migraine status was assessed with varying degrees of detail in the various cohorts, which also made us unable to look into possible differences between migraine with and without aura. Still, many cohorts used validated questionnaires based on ICHD criteria and have shown their effectiveness and precision in diagnosing migraine, ${ }^{1,15,18}$ which is why metabolite measure associations with migraine were chosen as main study outcome. To make a clear distinction between definite migraineurs and nonmigraine participants, we excluded probable migraine cases whenever possible. Additional variability due to sampling protocols used, foremost time-to-freezer and centrifuge settings, we aimed to control for by using meta-analysis approaches with a random-effects model. The low heterogeneity seen in the random-effects meta-analysis, in particular for the candidate biomarkers, seems to indicate that the aforementioned variability only had a limited influence on the study outcome. Our top metabolites related to HDL concentrations are known to be affected by BMI. Although we corrected for BMI in our analysis, we cannot exclude a residual confounding effect of this variable nor of any other variable that we have not tested. However, the robustness of our finding across different cohorts that differed in BMI distributions makes it likely that the HDL-related traits are truly associated with migraine. Genetic variability was limited because all cohorts were comprised predominantly of participants from the Netherlands, with Western European ancestry, but as a direct consequence the generalizability of our findings to other populations may be limited. The current study design does not allow the study of causality. Intervention or animal studies are needed to further explore the interplay between BMI, HDL-related traits, and migraine.
Another limitation of our multicohort design using distributed data analysis algorithms is that we cannot make definitive estimates of the sensitivity and specificity of the candidate biomarkers.

The current study illustrates the power of detailed metabolite profiling for biomarker discovery in a large meta-analytic design, pointing towards consistent associations of mainly medium to very large HDL measures with migraine. Furthermore, we identified a male-specific association between migraine status and omega-3 fatty acids. Our study suggests that alterations in HDL metabolism may be involved in the association between migraine and cerebrovascular and cardiovascular disease.

\section{Acknowledgment}

The authors thank the participants from the 8 cohorts participating in this study; A. Zhernakova and M.A. Louter, who assisted with recruitment of participants and sample collection; and V. Prasoodanan, who assisted with data-analysis. The Netherlands Twin Register thanks all twins and their relatives for their participation. The Erasmus Rucphen Family thanks all study participants and their relatives, general practitioners, and neurologists for their contributions and P. Veraart for help in genealogy, J. Vergeer for supervision of the laboratory work, and P. Snijders for help in data collection of both baseline and follow-up data. The authors thank the inhabitants, general practitioners, and pharmacists of the Ommoord district of the Rotterdam Study for their contributions.

\section{Study funding}

This work was performed within the framework of the Biobanking and BioMolecular resources Research Infrastructure (BBMRI) Metabolomics Consortium funded by BBMRI-NL, a research infrastructure financed by the Dutch government (Netherlands Organization for Scientific Research [NWO], no. 184.021.007 and 184033111). The Leiden University Migraine Neuro-Analysis (LUMINA) study is supported by grants obtained from the Netherlands Organization for the Health Research and Development (ZonMw; no. 90700217), NWO Gravitation Netherlands Organ-on-Chip Initiative (024.003.001); VIDI (ZonMw; no. 91711319) (to G.M.T.); NWO VICI (no. 918.56.602) and Spinoza prize (2009) grants (to M.D.F.); the Centre for Medical Systems Biology (CMSB) and Netherlands Consortium for Systems Biology (NCSB), both within the framework of the Netherlands Genomics Initiative (NGI)/NWO (to A.M.J.M.v.d.M.); and the FP7 EU project EUROHEADPAIN (no. 602633) (to M.D.F., A.M.J.M.v.d.M. \& G.M.T.). The Erasmus Rucphen Family (ERF) study has received funding from the Centre for Medical Systems Biology (CMSB) and Netherlands Consortium for Systems Biology (NCSB), both within the framework of NGI/NWO. The ERF study is part of EUROSPAN (European Special Populations Research Network) (FP6 STRP no. 018947 [LSHG-CT-2006-01947]); European Network of Genomic and Genetic Epidemiology (ENGAGE) from the European Community's Seventh Framework Programme (FP7/ 
2007-2013)/grant agreement HEALTH-F4-2007-201413; "Quality of Life and Management of the Living Resources" of FP5 (no. QLG2-CT-2002-01254); the "Internationale Stichting Alzheimer Onderzoek" (ISAO); the "Hersenstichting Nederland" (HSN); and the JNPD under the project PERADES (no. 733051021, Defining Genetic, Polygenic and Environmental Risk for Alzheimer's Disease using multiple powerful cohorts, focused Epigenetics and Stem cell metabolomics). This work has been performed as part of the CoSTREAM project (costream.eu) and has received funding from the European Union's Horizon 2020 research and innovation programme (no. 667375). Ayse Demirkan is supported by a VENI grant. The ERF follow-up study is funded by CardioVasculair Onderzoek Nederland (CVON 2012-03). The Rotterdam Study (RS) is supported by the Erasmus MC University Medical Centre and Erasmus University Rotterdam; NWO; The Netherlands Organisation for Health Research and Development (ZonMw); the Research Institute for Diseases in the Elderly (RIDE); NGI; the Ministry of Education, Culture and Science; the Ministry of Health, Welfare and Sports; the European Commission (DG XII); the JNPD under the project PERADES (no. 733051021, Defining Genetic, Polygenic and Environmental Risk for Alzheimer's Disease using multiple powerful cohorts, focused Epigenetics and Stem cell metabolomics); and the Municipality of Rotterdam. This work has been performed as part of the CoSTREAM project (costream.eu) and has received funding from the European Union's Horizon 2020 research and innovation programme (no. 667375). Netherlands Twin Register (NTR) is supported by funding from multiple grants from NWO and MagW/ZonMW (grants 904-61-090, 985-10-002, 904-61-193, 480-04-004, 400-05-717, 911-09-032); the Amsterdam Public Health (APH) institute; the Avera Institute, Sioux Falls, South Dakota; and the NIH (no. R01D004215701A, no. MH081802, no. 1RC2 MH089951). Computing was supported by BiG Grid, the Dutch e-Science Grid (NWO, no. 176.010.2005.009). R.P. was supported by BBRMI-NL (184.033.111). Also supported by grant NWO 480-15-001/ 674, Netherlands Twin Registry Repository (NWO Groot 48015-001/674), Netherlands Twin Registry Repository, and a Royal Netherlands Academy of Science Professor Award (PAH/6635) to D.I.B. The Netherlands Study of Depression and Anxiety (NESDA) (nesda.nl) infrastructure is funded through the Geestkracht program of the Netherlands Organisation for Health Research and Development (ZonMw, grant number 10-000-1002) and financial contributions by participating universities and mental health care organizations (VU University Medical Center, GGZ inGeest, Leiden University Medical Centre, Leiden University, GGZ Rivierduinen, University Medical Centre Groningen, University of Groningen, Lentis, GGZ Friesland, GGZ Drenthe, Rob Giel Onderzoekscentrum). The LifeLines Deep cohort is a subcohort of LifeLines, which has been funded by a number of public sources, notably the Dutch Government, NWO, the Northern Netherlands Collaboration of Provinces (SNN), the European fund for regional development, Dutch Ministry of Economic Affairs, Pieken in de Delta, Provinces of Groningen and Drenthe, the Target project, the University of Groningen, and the University
Medical Centre Groningen, the Netherlands. J.F. is supported by a VIDI (NWO: no. 864.13.013) grant and CardioVasculair Onderzoek Nederland (CVON 2012-03). L.F. is supported by a VIDI (NWO: no 917.14.374) and a European Research Council (ERC) Starting Grant 637640. C.W. is funded by an ERC advanced grant (FP/2007-2013/ERC grant 2012322698), a NWO Spinoza prize (NWO SPI 92-266), and the NWO Gravitation Netherlands Organ-on-Chip Initiative (024. 003.001), Top Institute of Food and Nutrition (TiFN GH0001), the Stiftelsen Kristian Gerhard Jebsen foundation (Norway), and the RuG investment agenda grant Personalized Health. The Maastricht Study is supported by the European Regional Development Fund as part of OP-ZUID; the Province of Limburg; the department of Economic Affairs of the Netherlands (no. 310.041); Stichting the Weijerhorst, the Pearl String Initiative Diabetes; the Cardiovascular Centre Maastricht; the Cardiovascular Research Institute Maastricht; School of Nutrition, Toxicology and Metabolism; Stichting Annadal; Health Foundation Limburg; and unrestricted grants from Janssen, Novo Nordisk, and Sanofi.

\section{Disclosure}

G. Onderwater, L. Ligthart, M. Bot, A. Demirkan, J. Fu, C. van der Kallen, L. Vijfhuizen, R. Pool, J. Liu, F. Vanmolkot, M. Beekman, K. Wen, N. Amin, C. Thesing, J. Pijpers, D. Kies, R. Zielman, I. de Boer, M. van Greevenbroek, I. Arts, Y. Milaneschi, M. Schram, P. Dagnelie, L. Franke, and M. Arfan Ikram report no disclosures relevant to the manuscript. M. Ferrari reports grants and consultancy or industry support from Medtronic. J. Goeman, P. Eline Slagboom, C. Wijmenga, C. Stehouwer, D. Boomsma, and C. van Duijn report no disclosures relevant to the manuscript. B. Penninx reports independent support from Jansen Research and Boehringer Ingelheim. P. 't Hoen reports no disclosures relevant to the manuscript. G. Terwindt reports grants and consultancy/industry support from Novartis. A. van den Maagdenberg reports no disclosures relevant to the manuscript. Go to Neurology.org/N for full disclosures.

\section{Publication history}

Received by Neurology July 20, 2018. Accepted in final form December 21, 2018.

\section{Appendix Authors}

\begin{tabular}{|c|c|c|c|}
\hline Name & Location & Role & Contributions \\
\hline $\begin{array}{l}\text { Gerrit L.J. } \\
\text { Onderwater, } \\
\text { MD }\end{array}$ & $\begin{array}{l}\text { Leiden University } \\
\text { Medical Center, the } \\
\text { Netherlands }\end{array}$ & Author & $\begin{array}{l}\text { Contributed to } \\
\text { design and } \\
\text { conceptualization of } \\
\text { the study, } \\
\text { contributed to data } \\
\text { collection and } \\
\text { interpretation, } \\
\text { contributed to } \\
\text { drafting a first } \\
\text { version of the } \\
\text { manuscript and } \\
\text { figures, and } \\
\text { interpreted the data } \\
\text { and revised the } \\
\text { manuscript }\end{array}$ \\
\hline
\end{tabular}


Appendix (continued)

\begin{tabular}{|c|c|c|c|}
\hline Name & Location & Role & Contributions \\
\hline $\begin{array}{l}\text { Lannie } \\
\text { Ligthart, PhD }\end{array}$ & $\begin{array}{l}\text { Vrije Universiteit } \\
\text { Amsterdam, the } \\
\text { Netherlands }\end{array}$ & Author & $\begin{array}{l}\text { Contributed to data } \\
\text { collection and } \\
\text { interpretation, } \\
\text { performed the } \\
\text { statistical analyses, } \\
\text { and interpreted the } \\
\text { data and revised the } \\
\text { manuscript }\end{array}$ \\
\hline $\begin{array}{l}\text { Mariska Bot, } \\
\text { PhD }\end{array}$ & $\begin{array}{l}\text { VU University } \\
\text { Medical Centre/ } \\
\text { GGZ inGeest, } \\
\text { Amsterdam, the } \\
\text { Netherlands }\end{array}$ & Author & $\begin{array}{l}\text { Contributed to data } \\
\text { collection and } \\
\text { interpretation, } \\
\text { performed the } \\
\text { statistical analyses, } \\
\text { and interpreted } \\
\text { the data and revised } \\
\text { the manuscript }\end{array}$ \\
\hline
\end{tabular}

\begin{tabular}{|c|c|c|c|}
\hline $\begin{array}{l}\text { Ayse } \\
\text { Demirkan, PhD }\end{array}$ & $\begin{array}{l}\text { Erasmus Medical } \\
\text { Centre, Rotterdam, } \\
\text { the Netherlands }\end{array}$ & Author & $\begin{array}{l}\text { Contributed to data } \\
\text { collection and } \\
\text { interpretation, and } \\
\text { interpreted the data } \\
\text { and revised the } \\
\text { manuscript }\end{array}$ \\
\hline
\end{tabular}

\begin{tabular}{lll}
\hline Jingyuan Fu, & University Medical Author & Contributed to data \\
PhD & Centre Groningen, & collection and \\
the Netherlands & interpretation, \\
& performed the \\
& statistical analyses, \\
& and interpreted the \\
& data and revised the \\
& manuscript
\end{tabular}

\begin{tabular}{|c|c|c|c|}
\hline $\begin{array}{l}\text { Carla J.H. van } \\
\text { der Kallen, PhD }\end{array}$ & $\begin{array}{l}\text { Maastricht } \\
\text { University Medical } \\
\text { Centre/Maastricht } \\
\text { University, the } \\
\text { Netherlands }\end{array}$ & Author & $\begin{array}{l}\text { Contributed to data } \\
\text { collection and } \\
\text { interpretation, and } \\
\text { interpreted the data } \\
\text { and revised the } \\
\text { manuscript }\end{array}$ \\
\hline
\end{tabular}

\begin{tabular}{|c|c|c|c|}
\hline $\begin{array}{l}\text { Lisanne S. } \\
\text { Vijfhuizen, BSc }\end{array}$ & $\begin{array}{l}\text { Leiden University } \\
\text { Medical Center, the } \\
\text { Netherlands }\end{array}$ & Author & $\begin{array}{l}\text { Contributed to data } \\
\text { collection and } \\
\text { interpretation, } \\
\text { performed the } \\
\text { statistical analyses, } \\
\text { and interpreted the } \\
\text { data and revised the } \\
\text { manuscript }\end{array}$ \\
\hline
\end{tabular}

\begin{tabular}{|c|c|c|c|}
\hline René Pool, PhD & $\begin{array}{l}\text { Vrije Universiteit } \\
\text { Amsterdam, the } \\
\text { Netherlands }\end{array}$ & Author & $\begin{array}{l}\text { Contributed to data } \\
\text { collection and } \\
\text { interpretation, } \\
\text { performed the } \\
\text { statistical analyses, } \\
\text { and interpreted } \\
\text { the data and } \\
\text { revised the } \\
\text { manuscript }\end{array}$ \\
\hline Jun Liu, MD & $\begin{array}{l}\text { Erasmus Medical } \\
\text { Centre, Rotterdam, } \\
\text { the Netherlands }\end{array}$ & Author & $\begin{array}{l}\text { Performed the } \\
\text { statistical analyses, } \\
\text { and interpreted the } \\
\text { data and revised the } \\
\text { manuscript }\end{array}$ \\
\hline $\begin{array}{l}\text { Floris H.M. } \\
\text { Vanmolkot, } \\
\text { MD, PhD }\end{array}$ & $\begin{array}{l}\text { Maastricht } \\
\text { University Medical } \\
\text { Centre/Maastricht } \\
\text { University, the } \\
\text { Netherlands }\end{array}$ & Author & $\begin{array}{l}\text { Contributed to data } \\
\text { collection and } \\
\text { interpretation, and } \\
\text { interpreted the data } \\
\text { and revised the } \\
\text { manuscript }\end{array}$ \\
\hline $\begin{array}{l}\text { Marian } \\
\text { Beekman, PhD }\end{array}$ & $\begin{array}{l}\text { Leiden University } \\
\text { Medical Center, the } \\
\text { Netherlands }\end{array}$ & Author & $\begin{array}{l}\text { Interpreted the data } \\
\text { and revised the } \\
\text { manuscript }\end{array}$ \\
\hline
\end{tabular}

Appendix (continued)

\begin{tabular}{|c|c|c|c|}
\hline Name & Location & Role & Contributions \\
\hline $\begin{array}{l}\text { Ke-xin Wen, } \\
\text { MD }\end{array}$ & $\begin{array}{l}\text { Erasmus Medical } \\
\text { Centre, Rotterdam, } \\
\text { the Netherlands }\end{array}$ & Author & $\begin{array}{l}\text { Contributed to data } \\
\text { collection and } \\
\text { interpretation, and } \\
\text { interpreted the data } \\
\text { and revised the } \\
\text { manuscript }\end{array}$ \\
\hline
\end{tabular}

\begin{tabular}{|c|c|c|c|}
\hline $\begin{array}{l}\text { Najaf Amin, } \\
\text { PhD }\end{array}$ & $\begin{array}{l}\text { Erasmus Medical } \\
\text { Centre, Rotterdam, } \\
\text { the Netherlands }\end{array}$ & Author & $\begin{array}{l}\text { Contributed to data } \\
\text { collection and } \\
\text { interpretation }\end{array}$ \\
\hline $\begin{array}{l}\text { Carisha S. } \\
\text { Thesing, MSc }\end{array}$ & $\begin{array}{l}\text { VU University } \\
\text { Medical Centre/ } \\
\text { GGZ inGeest, } \\
\text { Amsterdam, the } \\
\text { Netherlands }\end{array}$ & Author & $\begin{array}{l}\text { Performed the } \\
\text { statistical analyses, } \\
\text { interpreted the } \\
\text { data, and revised } \\
\text { the manuscript }\end{array}$ \\
\hline
\end{tabular}

\begin{tabular}{|c|c|c|c|}
\hline $\begin{array}{l}\text { Judith A. } \\
\text { Pijpers, MD }\end{array}$ & $\begin{array}{l}\text { Leiden University } \\
\text { Medical Center, the } \\
\text { Netherlands }\end{array}$ & Author & $\begin{array}{l}\text { Contributed to data } \\
\text { collection and } \\
\text { interpretation }\end{array}$ \\
\hline $\begin{array}{l}\text { Dennis A. Kies, } \\
\text { MD }\end{array}$ & $\begin{array}{l}\text { Leiden University } \\
\text { Medical Center, the } \\
\text { Netherlands }\end{array}$ & Author & $\begin{array}{l}\text { Contributed to data } \\
\text { collection and } \\
\text { interpretation }\end{array}$ \\
\hline $\begin{array}{l}\text { Ronald } \\
\text { Zielman, MD, } \\
\text { PhD }\end{array}$ & $\begin{array}{l}\text { Leiden University } \\
\text { Medical Center, the } \\
\text { Netherlands }\end{array}$ & Author & $\begin{array}{l}\text { Contributed to data } \\
\text { collection and } \\
\text { interpretation }\end{array}$ \\
\hline $\begin{array}{l}\text { Irene de Boer, } \\
\text { MD }\end{array}$ & $\begin{array}{l}\text { Leiden University } \\
\text { Medical Center, the } \\
\text { Netherlands }\end{array}$ & Author & $\begin{array}{l}\text { Performed the } \\
\text { statistical analyses, } \\
\text { interpreted the } \\
\text { data, and revised } \\
\text { the manuscript }\end{array}$ \\
\hline
\end{tabular}

\begin{tabular}{|c|c|c|c|}
\hline $\begin{array}{l}\text { Marleen M.J. } \\
\text { van } \\
\text { Greevenbroek, } \\
\text { PhD }\end{array}$ & $\begin{array}{l}\text { Maastricht } \\
\text { University Medical } \\
\text { Centre/Maastricht } \\
\text { University, the } \\
\text { Netherlands }\end{array}$ & Author & $\begin{array}{l}\text { Interpreted the data } \\
\text { and revised the } \\
\text { manuscript }\end{array}$ \\
\hline $\begin{array}{l}\text { Ilja C.W. Arts, } \\
\text { PhD }\end{array}$ & $\begin{array}{l}\text { Maastricht } \\
\text { University Medical } \\
\text { Centre/Maastricht } \\
\text { University, the } \\
\text { Netherlands }\end{array}$ & Author & $\begin{array}{l}\text { Contributed to data } \\
\text { collection and } \\
\text { interpretation }\end{array}$ \\
\hline $\begin{array}{l}\text { Yuri } \\
\text { Milaneschi, } \\
\text { PhD }\end{array}$ & $\begin{array}{l}\text { VU University } \\
\text { Medical Centre/ } \\
\text { GGZ inGeest, } \\
\text { Amsterdam, the } \\
\text { Netherlands }\end{array}$ & Author & $\begin{array}{l}\text { Interpreted the data } \\
\text { and revised the } \\
\text { manuscript }\end{array}$ \\
\hline
\end{tabular}

\begin{tabular}{|c|c|c|c|}
\hline $\begin{array}{l}\text { Miranda T. } \\
\text { Schram, PhD }\end{array}$ & $\begin{array}{l}\text { Maastricht } \\
\text { University Medical } \\
\text { Centre/Maastricht } \\
\text { University, the } \\
\text { Netherlands }\end{array}$ & Author & $\begin{array}{l}\text { Interpreted the data } \\
\text { and revised the } \\
\text { manuscript }\end{array}$ \\
\hline $\begin{array}{l}\text { Pieter C. } \\
\text { Dagnelie, PhD }\end{array}$ & $\begin{array}{l}\text { Maastricht } \\
\text { University Medical } \\
\text { Centre/Maastricht } \\
\text { University, the } \\
\text { Netherlands }\end{array}$ & Author & $\begin{array}{l}\text { Interpreted the data } \\
\text { and revised the } \\
\text { manuscript }\end{array}$ \\
\hline $\begin{array}{l}\text { Lude Franke, } \\
\text { PhD }\end{array}$ & $\begin{array}{l}\text { University Medical } \\
\text { Centre Groningen, } \\
\text { the Netherlands }\end{array}$ & Author & $\begin{array}{l}\text { Interpreted the data } \\
\text { and revised the } \\
\text { manuscript }\end{array}$ \\
\hline $\begin{array}{l}\text { M. Arfan Ikram, } \\
\text { MD, PhD }\end{array}$ & $\begin{array}{l}\text { Erasmus Medical } \\
\text { Centre, Rotterdam, } \\
\text { the Netherlands }\end{array}$ & Author & $\begin{array}{l}\text { Contributed to data } \\
\text { collection and } \\
\text { interpretation }\end{array}$ \\
\hline $\begin{array}{l}\text { Michel D. } \\
\text { Ferrari, MD, } \\
\text { PhD }\end{array}$ & $\begin{array}{l}\text { Leiden University } \\
\text { Medical Center, the } \\
\text { Netherlands }\end{array}$ & Author & $\begin{array}{l}\text { Interpreted the data } \\
\text { and revised the } \\
\text { manuscript }\end{array}$ \\
\hline
\end{tabular}


Appendix (continued)

\begin{tabular}{llll}
\hline Name & Location & Role & Contributions \\
\hline $\begin{array}{l}\text { Jelle J. Goeman, } \\
\text { PhD }\end{array}$ & $\begin{array}{l}\text { Leiden University } \\
\text { Medical Center, the } \\
\text { Netherlands }\end{array}$ & Author & $\begin{array}{l}\text { Contributed to data } \\
\text { collection and } \\
\text { interpretation and } \\
\text { statistical advice }\end{array}$ \\
\hline
\end{tabular}

P. Eline Leiden University Author Contributed to

Slagboom, PhD Medical Center, the design and Netherlands conceptualization

of the study, contributed to data collection and interpretation, interpreted the data, and revised the manuscript

\begin{tabular}{llll}
\hline $\begin{array}{l}\text { Cisca } \\
\text { Wijmenga, PhD }\end{array}$ & $\begin{array}{l}\text { University Medical } \\
\text { Centre Groningen, } \\
\text { the Netherlands }\end{array}$ & Author & $\begin{array}{l}\text { Interpreted the } \\
\text { data and revised } \\
\text { the manuscript }\end{array}$ \\
\hline $\begin{array}{l}\text { Coen D.A. } \\
\begin{array}{l}\text { Stehouwer, } \\
\text { MD, PhD }\end{array}\end{array}$ & $\begin{array}{l}\text { Maastricht } \\
\text { University Medical } \\
\text { Centre/Maastricht } \\
\text { University, the } \\
\text { Netherlands }\end{array}$ & Author & $\begin{array}{l}\text { Interpreted the } \\
\text { data and revised } \\
\text { the manuscript }\end{array}$ \\
& &
\end{tabular}

\begin{tabular}{ll}
\hline Dorret I. & Vrije Universiteit \\
Boomsma, PhD & $\begin{array}{l}\text { Amsterdam, the } \\
\text { Netherlands }\end{array}$
\end{tabular}

\section{Author Contributed to}

design and conceptualization of the study, contributed to data collection and interpretation, interpreted the data, and revised the manuscript

\begin{tabular}{|c|c|c|c|}
\hline $\begin{array}{l}\text { Cornelia M. van } \\
\text { Duijn, PhD }\end{array}$ & $\begin{array}{l}\text { Erasmus Medical } \\
\text { Centre, Rotterdam, } \\
\text { the Netherlands }\end{array}$ & Author & $\begin{array}{l}\text { Interpreted the data } \\
\text { and revised the } \\
\text { manuscript }\end{array}$ \\
\hline $\begin{array}{l}\text { Brenda W. } \\
\text { Penninx, PhD }\end{array}$ & $\begin{array}{l}\text { VU University } \\
\text { Medical Centre/ } \\
\text { GGZ inGeest, } \\
\text { Amsterdam, the } \\
\text { Netherlands }\end{array}$ & Author & $\begin{array}{l}\text { Contributed to data } \\
\text { collection and } \\
\text { interpretation, } \\
\text { interpreted the } \\
\text { data, and revised } \\
\text { the manuscript }\end{array}$ \\
\hline
\end{tabular}

\begin{tabular}{|c|c|c|c|}
\hline $\begin{array}{l}\text { Peter A.C. 't } \\
\text { Hoen, PhD }\end{array}$ & $\begin{array}{l}\text { Leiden University } \\
\text { Medical Center, the } \\
\text { Netherlands }\end{array}$ & Author & $\begin{array}{l}\text { Contributed to } \\
\text { design and } \\
\text { conceptualization } \\
\text { of the study, } \\
\text { contributed to } \\
\text { data collection and } \\
\text { interpretation, } \\
\text { statistical advice, } \\
\text { interpreted the data } \\
\text { and revised the } \\
\text { manuscript }\end{array}$ \\
\hline $\begin{array}{l}\text { Gisela M. } \\
\text { Terwindt, MD, } \\
\text { PhD }\end{array}$ & $\begin{array}{l}\text { Leiden University } \\
\text { Medical Center, the } \\
\text { Netherlands }\end{array}$ & Author & $\begin{array}{l}\text { Contributed to } \\
\text { design and } \\
\text { conceptualization } \\
\text { of the study, } \\
\text { contributed to data } \\
\text { collection and } \\
\text { interpretation, } \\
\text { interpreted the } \\
\text { data, and revised } \\
\text { the manuscript }\end{array}$ \\
\hline
\end{tabular}

Appendix (continued)

\begin{tabular}{|c|c|c|c|}
\hline Name & Location & Role & Contributions \\
\hline $\begin{array}{l}\text { Arn M.J.M. } \\
\text { van den } \\
\text { Maagdenberg, } \\
\text { PhD }\end{array}$ & $\begin{array}{l}\text { Leiden University } \\
\text { Medical Center, the } \\
\text { Netherlands }\end{array}$ & Author & $\begin{array}{l}\text { Contributed to } \\
\text { design and } \\
\text { conceptualization of } \\
\text { the study, } \\
\text { contributed to data } \\
\text { collection and } \\
\text { interpretation, } \\
\text { interpreted the } \\
\text { data, and revised } \\
\text { the manuscript }\end{array}$ \\
\hline
\end{tabular}

\section{References}

1. Launer LJ, Terwindt GM, Ferrari MD. The prevalence and characteristics of migraine in a population-based cohort: the GEM study. Neurology 1999;53:537-542.

2. Stovner LJ, Zwart JA, Hagen K, Terwindt GM, Pascual J. Epidemiology of headache in Europe. Eur J Neurol 2006;13:333-345.

3. Jensen R, Stovner LJ. Epidemiology and comorbidity of headache. Lancet Neurol 2008;7:354-361.

4. GBD 2016 Disease and Injury Incidence and Prevalence Collaborators. Global, regional, and national incidence, prevalence, and years lived with disability for 328 diseases and injuries for 195 countries, 1990-2016: a systematic analysis for the Global Burden of Disease Study 2016. Lancet 2017;390:1211-1259.

5. Kurth T, Schürks M, Logroscino G, Gaziano JM, Buring JE. Migraine, vascular risk, and cardiovascular events in women: prospective cohort study. BMJ 2008;337:a636

6. Kurth T, Chabriat H, Bousser MG. Migraine and stroke: a complex association with clinical implications. Lancet Neurol 2012;11:92-100.

7. Schürks M, Rist PM, Bigal ME, Buring JE, Lipton RB, Kurth T. Migraine and cardiovascular disease: systematic review and meta-analysis. BMJ 2009;339:b3914

8. Kurth T, Winter AC, Eliassen AH, et al. Migraine and risk of cardiovascular disease in women: prospective cohort study. BMJ 2016;353:i2610.

9. Stam AH, Weller CM, Janssens AC, et al. Migraine is not associated with enhanced atherosclerosis. Cephalalgia 2013;33:228-235.

10. van Os HJA, Mulder IA, Broersen A, et al. Migraine and cerebrovascular atherosclerosis in patients with ischemic stroke. Stroke 2017;48:1973-1975.

11. Bigal ME, Kurth T, Hu H, Santanello N, Lipton RB. Migraine and cardiovascular disease: possible mechanisms of interaction. Neurology 2009;72:1864-1871.

12. Lipton RB. Inflaming the need for migraine biomarkers. Neurology $2014 ; 83$ 2198-2199.

13. Tietjen GE, Khubchandani J. Vascular biomarkers in migraine. Cephalalgia 2015;35: 95-117.

14. Soininen P, Kangas AJ, Würtz P, Suna T, Ala-Korpela M. Quantitative serum nuclear magnetic resonance metabolomics in cardiovascular epidemiology and genetics. Circ Cardiovasc Genet 2015;8:192-206.

15. van Oosterhout WPJ, Weller CM, Stam AH, et al. Validation of the web-based LUMINA questionnaire for recruiting large cohorts of migraineurs. Cephalalgia 2011 31:1359-1367.

16. Penninx BW, Beekman AT, Smit JH, et al. The Netherlands Study of Depression and Anxiety (NESDA): rationale, objectives and methods. Int J Methods Psychiatr Res 2008; $17: 121-140$.

17. Boomsma DI, de Geus EJ, Vink JM, et al. Netherlands Twin Register: from twins to twin families. Twin Res Hum Genet 2006;9:849-857.

18. Stam AH, de Vries B, Janssens AC, et al. Shared genetic factors in migraine and depression: evidence from a genetic isolate. Neurology 2010;74:288-294.

19. Sleegers K, de Koning I, Aulchenko YS, et al. Cerebrovascular risk factors do not contribute to genetic variance of cognitive function: the ERF study. Neurobiol Aging 2007;28:735-741.

20. Hofman A, van Duijn CM, Franco OH, et al. The Rotterdam Study: 2012 objectives and design update. Eur J Epidemiol 2011;26:657-686.

21. Schram MT, Sep SJ, van der Kallen CJ, et al. The Maastricht Study: an extensive phenotyping study on determinants of type 2 diabetes, its complications and its comorbidities. Eur J Epidemiol 2014;29:439-451.

22. Stolk RP, Rosmalen JGM, Postma DS, et al. Universal risk factors for multifactorial diseases: LifeLines: a three-generation population-based study. Eur J Epidemiol 2008; 23:67-74.

23. Scholtens S, Smidt N, Swertz MA, et al. Cohort Profile: LifeLines, a three-generation cohort study and biobank. Int J Epidemiol 2015;44:1172-1180.

24. Headache Classification Committee of the International Headache Society (IHS). The International Classification of Headache Disorders, 3rd edition (beta version). Cephalalgia 2013;33:629-808.

25. Headache Classification Committee of the International Headache Society (IHS). The international Classification of Headache Disorders: 2nd edition. Cephalalgia 2004;24(suppl 1):9-160.

26. Goek ON, Döring A, Gieger C, et al. Serum metabolite concentrations and decreased GFR in the general population. Am J Kidney Dis 2012;60:197-206.

27. Holm S. A simple sequentially rejective multiple test procedure. Scand J Stat 1979;6: $65-70$. 
28. Goeman JJ, Van de Geer S, De Kort F, van Houwellingen HC. A global test for groups for genes: testing association with a clinical outcome. Bioinformatics 2004;20:93-99.

29. Hendrickx DM, Hoefsloot HCJ, Hendriks MMWB, Canelas AB, Smilde AK. Global test for metabolic pathway differences between conditions. Anal Chim Acta 2012;719: $8-15$.

30. Wahl S, Vogt S, Stückler F, et al. Multi-omic signature of body weight change: results from a population-based cohort study. BMC Med 2015;13:48.

31. Fisher RA. Statistical Methods for Research Workers, 5th ed. London: Oliver \& Boyd; 1934.

32. Bassi B, Parodi E, Messina M, et al. Screening for genetic and acquired thrombophilia in a cohort of young migrainous patients. J Headache Pain 2003;4:138-145.

33. Ferraris E, Marzocchi N, Brovia D, Castellana CN, Pini LA. Homocysteine levels and cardiovascular disease in migraine with aura. J Headache Pain 2003;4:62-66.

34. Kurth T, Ridker PM, Buring JE. Migraine and biomarkers of cardiovascular disease in women. Cephalalgia 2008;28:49-56.

35. Maghsoumi-Norouzabad L, Monsoori A, Abed R, Shishehbor F. Effects of omega-3 fatty acids on the frequency, severity, and duration of migraine attacks: a systematic review and meta-analysis of randomized controlled trials. Nutr Neurosci 2018;21: 614-623.

36. O'Connell BJ, Genest J Jr. Current perspective: high-density lipoproteins and endothelial function. Circulation 2001;104:1978-1983.

37. Navab M, Anantharamaiah GM, Reddy ST, Van Lenten BJ, Fogelman AM. HDL as a biomarker, potential therapeutic target, and therapy. Diabetes 2009;58:2711-2717.

38. Tietjen GE. Migraine as a systemic vasculopathy. Cephalalgia 2009;29:987-996.

39. Serhan CN, Chiang N, Van Dyke TE. Resolution lipid mediators. Nat Rev Immunol $2008 ; 8: 349-361$.

40. Nguyen LN, Ma D, Shui G, et al. Mfsd2a is a transporter for the essential omega-3 fatty acid docosahexaenoic acid. Nature 2014; 509:503-506.

41. Wang H, Eckel RH. What are lipoproteins doing in the brain? Trends Endocrinol Metab 2014;25:8-14.

42. Vitali C, Wellington CL, Calabresi L. HDL and cholesterol handling in the brain. Cardiovasc Res 2014;103:405-413.

43. van der Lee SJ, Teunissen CE, Pool R, et al. Circulating metabolites and general cognitive ability and dementia: evidence from 11 cohort studies. Alzheimer Dement 2018; $14: 707-722$ 


\section{Neurology}

\section{Large-scale plasma metabolome analysis reveals alterations in HDL metabolism in migraine}

Gerrit L.J. Onderwater, Lannie Ligthart, Mariska Bot, et al.

Neurology 2019;92;e1899-e1911 Published Online before print April 3, 2019

DOI 10.1212/WNL.0000000000007313

This information is current as of April 3, 2019

\section{Updated Information \& Services}

References

Citations

Subspecialty Collections

Permissions \& Licensing

Reprints including high resolution figures, can be found at: http://n.neurology.org/content/92/16/e1899.full

This article cites 42 articles, 11 of which you can access for free at: http://n.neurology.org/content/92/16/e1899.full\#ref-list-1

This article has been cited by 1 HighWire-hosted articles: http://n.neurology.org/content/92/16/e1899.full\#\#otherarticles

This article, along with others on similar topics, appears in the following collection(s):

All Cerebrovascular disease/Stroke

http://n.neurology.org/cgi/collection/all_cerebrovascular_disease_strok e

Central pain

http://n.neurology.org/cgi/collection/central_pain

Cohort studies

http://n.neurology.org/cgi/collection/cohort_studies

Migraine

http://n.neurology.org/cgi/collection/migraine

Risk factors in epidemiology

http://n.neurology.org/cgi/collection/risk_factors_in_epidemiology

Information about reproducing this article in parts (figures,tables) or in its entirety can be found online at:

http://www.neurology.org/about/about_the_journal\#permissions

Information about ordering reprints can be found online:

http://n.neurology.org/subscribers/advertise

Neurology ${ }^{\circledR}$ is the official journal of the American Academy of Neurology. Published continuously since 1951, it is now a weekly with 48 issues per year. Copyright Copyright ( 2019 The Author(s). Published by Wolters Kluwer Health, Inc. on behalf of the American Academy of Neurology.. All rights reserved. Print ISSN: 0028-3878. Online ISSN: 1526-632X.

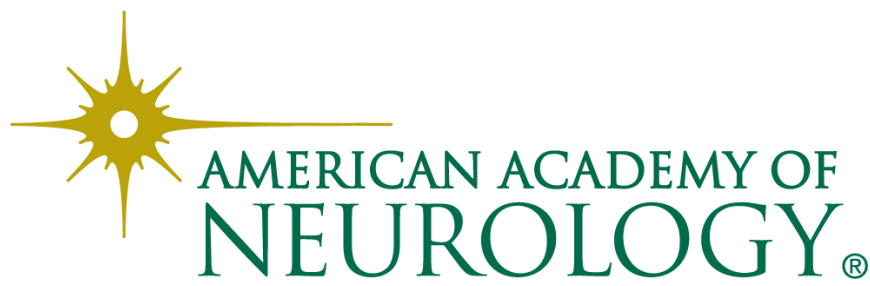

